\title{
ICOM \\ Instagram and the science museum: a missed opportunity for public engagement
}

\section{Paige Brown Jarreau, Nicole Smith Dahmen and Ember Jones}

\begin{abstract}
Science museums are missing an opportunity to promote informal education, scientific literacy, public engagement and public visibility of scientists outside of museum walls via Instagram. With an analysis of 1,073 Instagram posts, we show that museums are using Instagram as a promotional broadcasting tool, with a focus on end results of collections and curation work over communication of museum-led discovery and science as a process. We suggest that science museums create more Instagram posts that offer educational information and visibility of exhibit creation and museum researchers' work behind the scenes.
\end{abstract}

Keywords Informal learning; Public engagement with science and technology; Science centres and museums

DOI

https://doi.org/10.22323/2.18020206

Submitted: 3rd February 2018

Accepted: 27th March 2019

Published: 8th April 2019

Social media networks have revolutionized science communication [Brossard, 2013; Welbourne and Grant, 2016; Mollett et al., 2017]. Scientists as individuals have embraced social media [Bik and Goldstein, 2013; Van Noorden, 2014; Bombaci et al., 2016; Collins, Shiffman and Rock, 2016; Sugimoto et al., 2017] to digitally enhance their scholarship, initiate collaborations [Shanahan, 2011] and communicate with broader audiences [Bonetta, 2007; Lapointe and Drouin, 2007; Luzón, 2013; Puschmann, 2014]. Museum and life science researchers are prominent among scientists embracing social media for public engagement [Ke, Ahn and Sugimoto, 2017], as evidenced by the popularity of the \#AskACurator hashtag on Twitter and Instagram. ${ }^{1}$ However, we know little about how museums as institutions are using social media to engage their audiences.

Young museum visitors belong to a generation eager to experience cultural artifacts and museum exhibits through a new lens, one where the experience is enhanced, filtered and shared through personal online social networks [Russo, Watkins and Groundwater-Smith, 2009]. Kylie Budge [2017] writes that museums have much to gain from "observing and 'listening to' their audiences" and that "Instagram, as a

\footnotetext{
${ }^{1}$ https://twitter.com/askacurator.
} 
highly visual social media, stands centre stage as a platform in which visitors are sharing [their museum] experiences" (p. 70). Audiences today demand from organizations, including museums, greater levels of interaction and engagement, which social media can facilitate [Mangold and Faulds, 2009; Lovejoy and Saxton, 2012]. Museums have slowly turned to social media [Badell, 2015] to disseminate information, promote their programs and interact with their publics in order to remain relevant in the digital age. They can use social media to meet audiences where they are (U.S. adults and teens are increasingly getting their science news and information online) and to enhance learning [Russo, Watkins and Groundwater-Smith, 2009; Weilenmann, Hillman and Jungselius, 2013].

Instagram is a visually focused social network that science museums and their staff, curators and researchers have begun to adopt to reach new audiences [Weilenmann, Hillman and Jungselius, 2013]. Instagram caters to the visual nature of museum work and may serve as a tool for education and engagement of young adults who may only occasionally visit museums in person. Museums strive to preserve history and make discoveries and specimens tangible, visible and accessible for visitors. Instagram can support digital interaction with museum artifacts and more importantly the people behind museum discoveries. The goal of this study was to answer, through a quantitative content analysis, basic questions about how science museums are using Instagram and if they are using it to promote museum activities, disseminate scientific information, share research/collections work and/or foster public engagement.

\section{Context}

\section{Instagram}

Instagram is a social network and multimedia sharing platform designed primarily for use on mobile devices. It currently allows users to upload images in various formats as well as video clips up to 60 seconds in length, to apply a range of filters to these visuals, to add captions to and tag other users, and to publish these posts or stories publicly or send them directly to individual users. A user's Instagram posts appear on the account's timeline, in reverse chronological order, such that narrative can also be created through time [Weilenmann, Hillman and Jungselius, 2013]. Instagram has grown rapidly since its launch in 2010, with more than 500 million users as of June 2016 [Instagram, 2016]. It also presents science museums an opportunity to reach a potentially more diverse audience than present on other social media platforms [Duggan, 2015; Salomon, 2013] with visually-oriented, engaging content.

The recent adoption of Instagram by educators [Salomon, 2013] and museums [Jensen, 2013; Weilenmann, Hillman and Jungselius, 2013] complements the steady increase of online photo and video sharing among U.S. adults within the last decade. From Pew Research Center data published in 2015, 28\% of adult internet users or $24 \%$ of the U.S. adult population use Instagram, with women, Blacks and Hispanics, and younger adults more likely to use this social network. Since its launch in 2010, the now Facebook-owned Instagram has become a popular venue for science communication, especially among female scientists. ${ }^{2}$

\footnotetext{
${ }^{2} \mathrm{~A}$ recent index of scientists on Instagram created through the \#ScientistsWhoSelfie project, includes nearly 300 scientists' accounts, http:/ / bit.ly/IGscientistsindex.
} 
Most science museums today have goals that include knowledge creation, information dissemination, informal education, public engagement and participation with science [Kelly, 2010]. It's unclear whether and how museums have used social media to support these goals. Museum visitors have become accustomed to getting information in multimedia formats that they can interact with, take with them and share with friends online, and yet museums are still sharing their collections work and discoveries in much the same way they did before the rise of the internet - through objects and written scientific documents as opposed to through live multimedia "journeys" through collections work and field excursions, for example [Bandelli and Konijn, 2013]. A 2010 study referred to the uptake of web 2.0 tools by museums as "patchy" and slow [Kelly, 2010]. However, more recent studies indicate that museum curators have eagerly adopted social media tools including Instagram to share their curatorial work and life [Fisher, 2016; Marty, 2016]. While it's clear that museum professionals believe that "becoming involved with social media is important," [Fletcher and Lee, 2012], research indicates that museums are underutilizing social networks or misusing them as traditional, one-way, promotional messaging channels [Fletcher and Lee, 2012; Lazzeretti, Sartori and Innocenti, 2015]. This study is unique in investigating how science museums are using their official Instagram accounts to communicate museum work, promote informal learning, interact with visitors and encourage public engagement with science - all common missions of the modern science museum.

\section{User-based science communication approaches}

Previous research has established the key motivational factors that drive reader/viewer use of science-based social media content, from a uses and gratifications theoretical perspective. These include information-driven motivations, entertainment-driven motivations, community-seeking motivations and guidance-seeking motivations [Jarreau and Porter, 2016; Lee and Chyi, 2014]. Science museums are likely to use their social media channels as promotional platforms. However, there is pressure for modern organizations to be more user-centered in their communication approaches and strategies [Wright and Hinson, 2008], for example by posting content that entertains, caters to specific audiences' information needs or fosters engagement and dialogue between experts and lay audiences. We investigate the overarching communication approaches adopted by science museums on Instagram by quantifying the extent to which their posts focus on promotion (museum-centered) or delivery of scientific information, entertainment and engagement via calls to action (user-centered).

\section{Informal learning inside and outside of the museum}

Social networks are potential venues for informal science education and learning [Russo, Watkins and Groundwater-Smith, 2009; Sefton-Green, 2004; Su et al., 2015]. They offer access to networked knowledge [Cornu, 2004]. Instagram combines key factors for learning [Green and Hannon, 2006]: it allows users to share knowledge, search for information via hashtags, apply that information through user-generated visuals and reflect on their new knowledge through re-posting and captioning features, for example. 
Science museums could be using Instagram to promote scientific literacy, not just through artifact-centered information but through exposure to the scientific process or science-in-the-making [Hine and Medvecky, 2015] and museum researchers. Museums have historically been key players in the production and dissemination of new scientific knowledge. However, through the nineteenth century the museum often became more of a "trophy chest" of history and artifacts [Arnold, 1996]. Hine and Medvecky [2015] refer to museum "products" or artifacts as "finished science," writing: "While this objective, finished version of science is important for grasping the mechanics of scientific principles, it is the teaching of methodologies and an immersion into the continuous evolution of knowledge that is required for a fuller understanding" (p. 1). In recent decades, the concept of the science museum as a place of research in progress has re-emerged. Many museums today are trying to promote their active roles in scientific knowledge making and discovery, for example with behind-the-scenes tours of research collections. ${ }^{3}$ Arnold [1996] found that "a number of [museum] exhibitions have moved the central question on from what science does to how scientists do it" (p. 58). Science museums are being pushed by a variety of factors, including the explosion of entertainment media and social media, to present science as an active process as opposed to a series of already discovered artifacts [Arnold, 1996]. They might do so by providing research updates and behind-the-scenes glimpses of museum work in action through their social media channels.

\section{Public engagement}

Public engagement reflects a shift in the scientific community's approach toward science communication, away from a deficit or one-way communication model focused on filling knowledge "gaps" [Wooden, 2006; Druckman and Bolsen, 2011] and toward two-way, dialogue and participation-based approaches [Sturgis and Allum, 2004; Schäfer, 2009; Bandelli and Konijn, 2013; Illingworth et al., 2015]. Science museums, centers and zoos are among the few modern public venues where citizens can interact directly with scientists' work and scientific discovery. Several science museums and centers have made shifts to promote public engagement [Rudloff, 2013], for example by allowing visitors to access and participate in research collections and laboratory spaces [Bowler, Buchanan-Smith and Whiten, 2012]. Some museums have begun to promote and incorporate participatory citizen science activities into their exhibits as well as research and collections work $^{4,5}$ [Hill et al., 2012; Roger and Klistorner, 2016; Ballard et al., 2017; Spear, Pauly and Kaiser, 2017]. These activities are beneficial in terms of increasing the time that visitors spend at museums [Bowler, Buchanan-Smith and Whiten, 2012], building public trust in science [Fiske and Dupree, 2014], increasing public understanding of the scientific process and interest in science [Stilgoe, Lock and Wilsdon, 2014] and building capacity for evidence-based decision making [Jensen and Buckley, 2014; Bonney et al., 2015; Selin et al., 2016]. Science museums could not only be communicating about these activities more often but also directly

\footnotetext{
${ }^{3}$ Examples of museums providing behind-the-scenes tours and exposure to scientists: http:/ /suscienceblog.squarespace.com/blog/2016/9/30/virtual-tour-of-the-lsu-museum-ofnatural-science, https://nhm.org/site/activities-programs/behind-the-scenes-tours, https: / / www.amnh.org/explore/news-blogs / from-the-collections-posts/special-tours-takemembers-behind-the-scenes/.

${ }^{4}$ https:/ / www.fieldmuseum.org/science/citizen-science.

${ }^{5}$ http:/ / naturalsciences.org/research-collections/citizen-science.
} 
promoting engagement through their social media channels. They might encourage public engagement via mobilizing Instagram posts that invite viewers to participate in knowledge creation [Ballard et al., 2017], as in the "Monitor Change" projects ${ }^{6}$ where citizens are asked to monitor environmental changes through smartphone photo contributions in specific areas, ask museum curators questions (e.g. \#askacurator) and participate in field collection activities, for example.

\section{The human element and portrayal of scientists}

In general, people see scientists as competent but not relatable, warm and friendly [Fiske and Dupree, 2014]. This ambivalent view of scientists isn't helped by historical media portrayals of scientists as mysterious, eccentric, antisocial, aloof or even "mad", amoral and dangerous [Long and Steinke, 1996; Nisbet et al., 2002]. Even though stereotypes about scientists have become less pronounced and negative over the last decade [Losh, 2010], there is still room for improvement in terms of public perceptions of scientists as individuals who are not only intelligent and competent, but also relatable, friendly, "warm" and trustworthy and who look or behave "like me" [Fiske and Dupree, 2014]. In reaction to science stereotypes, has been a movement among modern communities of scientists and science communicators to create visual portrayals of scientists that counter stereotypes and to offer audiences a view inside the lives of scientists, such as via social media campaigns including \#actuallivingscientist on Twitter and \#scientistswhoselfie on Instagram. However, few studies have investigated how museums and other public science institutions are or aren't helping to change stereotypes of scientists through the visuals they share on social media. For example, museums could help audiences get to know museum staff and researchers, what they look like and what they do on a daily basis, through Instagram visuals and captions. We investigate how science museums are approaching this issue in terms of posting visuals of their curators, lab managers and researchers in action.

Research questions

We conducted an exploratory study of science museum Instagram content, centered on the following research questions:

RQ1: What fields of science are most prominently represented in the Instagram posts of science museums?

RQ2: What types of content are most often the focus of posts within the Instagram accounts of science museums?

RQ3: How often do science museums' Instagram visuals include a human element (e.g. human faces) and what types of individuals are most prominently portrayed?

RQ4: To what extent is science museum Instagram content information-driven, promotional and/or engagement-driven?

RQ4a: How is the communication model reflected in a post related to post engagement in terms of likes and comments?

\footnotetext{
${ }^{6}$ http://nerdsfornature.org/monitor-change/.
} 
RQ5: To what extent are the Instagram accounts of science museums portraying public engagement or participation in science?

RQ6: How is scientific research portrayed in science museums' Instagram posts, e.g. to what extent are science museums communicating their research activities and to what extent are they portraying science as a process of discovery?

RQ7: Are science museum Instagram posts directly promoting informal science learning?

Data were collected via a quantitative content analysis [Riffe, Lacy and Fico, 2005]. Two independent coders analyzed a list of 1,080 individual science museum Instagram posts. The coders recorded all data digitally via a Qualtrics questionnaire, with coding facilitated by the use of a comprehensive codebook. The researchers and the coders reviewed the coding protocol and operational definitions in several training sessions; using the protocol, an unrelated sample of similar content was coded in these training sessions. The researchers and the coders reviewed individual photos to arrive at a "common understanding" of coding categories and "borderline cases." This type of consensus coding is similar to the method employed in Fink and Schudson's [2014] study on changes in news content since 1950. As Fink and Schudson [2014] note, no coding is "foolproof" (p. 12). Coding social media content presents its own share of coding challenges [Riffe, Lacy and Fico, 2005].

The unit of analysis was a single Instagram post within the main feed. The final sample of Instagram posts were content analyzed on 28 variables related to the format and popularity of the visual, content of the visual, appeal of the post as a whole, and content of the caption (see Codebook in supplementary material).

\section{Identification of science museum Instagram accounts}

We defined our target as museums or centers that prominently feature exhibits or other content related to science, technology, engineering and math. We included museums of art and science, natural history museums, medical museums, engineering-related museums such as the Museum of Flight, and history of science museums. While zoos, aquariums and botanical gardens are closely related to science museums, we did not include these types of accounts in this study, but these may be the target of future studies. Based on several online indexes ${ }^{7,8}$ of U.S. science museums and centers, we created a list of 211 Instagram accounts, ranging from 20 followers to 337,000 followers. Instagram accounts that contained zero posts or that were outdated (most recent post over six months old) were excluded from our list.

\footnotetext{
${ }^{7}$ List of science centers in the United States, Wikipedia. https:/ / en.wikipedia.org/wiki/List_of_science_centers_in_the_United_States.

${ }^{8}$ American Alliance of Museums, museum directory http:/ / www.aam-us.org/about-museums/find-a-museum.
} 
Sample

The final sample of Instagram posts selected for content analysis consisted of the most recent 10 images (as of October 2016) from each Instagram account in our final index with over 1,000 followers. We chose to analyze 10 images from each account and to limit accounts in the final sample to those with over 1,000 followers in order to investigate a greater depth of content from a smaller number of accounts. The final sample consisted of 10 pre-designated images from 108 Instagram accounts.

\section{Coding form and codebook development}

We developed and refined a coding form for quantitative content analysis based upon both previous literature investigating science visuals and an initial researcher-led coding of over 100 posts pulled from our final index but not included in our final sample. These included posts from science museum accounts in our originally curated list with at least 100 followers but less than 1,000 followers. To aid our two independent coders in their analysis of all Instagram posts, we developed a codebook complete with detailed instructions on coding protocol. This codebook included examples of Instagram posts that fit the various code categories.

\section{Measures}

Format variables. Instagram posts were coded on format variables including color (color or black and white) and type of visual. Other format variables included the scale of the visual (normal or what the human eye could see, microscope-scale, telescope-scale, or a mix) and the distance to the primary subject in the visual (extreme close-up, close-up, full shot, landscape, or a mix).

Popularity variables. Instagram posts were coded on popularity variables evaluated at the time of coding. These variables included number of likes (for photos) or views (for videos), and number of comments for all posts.

Source variables. Instagram visuals were coded as either published directly by the museum or re-posted from another Instagram account. If re-posted from another account, the posts were coded on account source (a museum visitor, a museum staff member, a science professional, or other).

Visual content variables. Instagram posts were coded on a variety of content variables. The posts in the final sample were coded for presence (as the primary or an important aspect of the visual) of a number of content elements that emerged as common elements/themes in an initial coding of over 100 test images. These included (a) a completed museum exhibit or part of the exhibit on display in a museum, behind the scenes of (b) museum research, curation, collections work (e.g. visuals of scientific research in progress), or (c) museum activities NOT related to research, curation or collections, $(\mathrm{d})$ a science demonstration or hands-on science activity involving museum visitors, (e) other museum activity, (f) identified or (g) unidentified scientific specimen(s) or natural object(s), and (h) a (scientific) technology. Posts were also coded on content variables including primary scientific topic or field of science portrayed, and setting. 
Research communication and science as a process variables. Posts were also coded for whether they presented information related to a new (within the last year) research finding or discovery, and whether or not they depicted science as a process versus a product.

Public engagement with science. Posts were coded for whether they depicted meaningful public engagement with science. This variable was operationalized as non-scientists talking to scientists, engaging in hands-on / citizen science activities or meaningfully interacting with science via museum exhibits. Visuals that depicted museum visitors as passive viewers of exhibits, that depicted visitors engaging in fun activities only loosely connected with scientific discovery, or that did not include any human elements, were coded as not depicting public engagement with science.

Instagram post communication approach variables. Based on the overall appeal of an Instagram post, coders designated the extent to which each post (including both the visual and caption) contained content characterized by the following communication approaches: 1) Informational (educates and/or spreads scientific information or facts), 2) Entertainment-driven (entertaining in nature), 3) Promotional (promotes a museum exhibit, facility, activity, etc., 4) Mobilizing (content that calls to action). Each post was coded as being dominated, somewhat dominated or not at all dominated by each of the above approaches.

Instagram post appeal variable. Instagram posts were coded on both tonality (positive, negative or neutral) and overall emotional appeal (wonder/awe/excitement, humor/funny, anger, anxiety/fear, sadness, nostalgia, no emotional appeal or other), taking into account both aspects of the post visuals as well as captions.

Human element and portrayal of scientists variables. Instagram posts were coded on presence of a human element and type of human element portrayed. If at least one individual was portrayed in the visual, coders designated whether or not the post portrayed individuals identified or clearly depicted as science professionals, historical science figures, other museum staff/volunteers, children, news media professionals, celebrities, policymakers/public figures and/or technicians/IT. If the post portrayed any science professionals, coders designated the gender and race of each science professional when identifiable, and coded the context in which the science professional(s) were shown, e.g. either a research context, other professional context (giving a science talk, doing non-research museum work, etc.), a private context (engaging in hobbies or private matters, etc.), or other context.

Caption variables. Posts were coded on presence of hashtag and type of hashtag variables. Coders noted whether post hashtags were science-related or not, museum or campaign branded or not, and inspirational/comical or not. Finally, the captions were coded on scientific content, e.g. whether or not they contained substantial scientific content, operationalized as more than just a one-liner description of the content of the visual. 
Our sample consisted of 10 chronological images (pre-selected in October, 2016) from a total of 108 museum Instagram accounts, representing a range of science and technology museums, with over 1,000 followers. We also included a selection of accounts managed by scientific organizations involved in public outreach and tours, including facilities such as the NASA Jet Propulsion Laboratory and Woods Hole Oceanographic Institution. The analyses below are based on 1,073 Instagram posts; seven posts from the original sample were not included because between the time of curating and coding the sample, these posts had been deleted.

\section{Format, source and popularity of analyzed Instagram posts}

A majority of posts or $90 \%(\mathrm{n}=967)$ were created/published by the museum as opposed to being reposted from another account. Of those reposted $(n=106), 43 \%$ were reposted from a museum visitor. A majority of the visuals or $95 \%(n=1016)$ were in color as opposed to black and white, while $72 \%{ }^{9}(n=773)$ were traditional stills, with only a handful of these being selfies. Less common formats were unedited videos $(5 \%, \mathrm{n}=53)$, promotional flyers/graphics $(9 \%, \mathrm{n}=81)$, crafted or edited videos $(3 \%, n=32)$ and photo collages $(4 \%, n=43)$. Only a handful of the posts were infographics, illustrations, scientific animations, cartoons/memes or Instagram video "boomerangs." A majority of the posts included content at the scale that the human eye could see normally $(93 \%, n=991)$ as opposed to being microscope or telescope-captured images, for example $(2 \%, n=21)$. For a small number of posts scale wasn't applicable, for example text-based graphics $(5 \%, \mathrm{n}=$ 52). Most of the visuals were medium distance shots $(40 \%, \mathrm{n}=422)$ or close-ups $(37 \%, \mathrm{n}=393)$ with respect to the primary subject, while a small number were landscape or outer space shots $(6 \%, \mathrm{n}=67)$ or extreme close-ups with the main subject of the visual filling the entire frame $(7 \%, n=73)$. For the rest of the posts, scale was either not applicable or was mixed $(11 \%, n=117)$.

A majority or $55 \%(n=591)$ of the posts had fewer than 100 likes / views at the time of coding. A third of the posts $(\mathrm{n}=348)$ had between 100 and 500 likes/views, $4 \%(n=42)$ had between 500 and 1,000 likes/views, $6 \%(n=68)$ had between 1,000 and 5,000 likes/views, and only $2 \%(n=21)$ had more than 5,000 views/likes. The mean number of comments per post was 3.2, with a maximum of 174 comments. A majority or $58 \%$ of the posts had either zero comments $(37 \%, n=401)$ or one comment $(20 \%, \mathrm{n}=223)$.

\section{Science topic areas in museum accounts}

We addressed RQ1 by investigating identifiable topic areas or fields of science represented in the museum Instagram posts. The most well-represented were zoology / animal science / wildlife conservation ( $14 \%$ of posts, $\mathrm{n}=149)$, engineering $(11 \%, n=119)$ and archeology / paleontology $(8 \%, n=81)$. See Table 1 . A large portion of the posts featured no science related content $(31 \%$ of posts, $n=$ 336) or items/contexts that appeared to be science-related but where the field was not mentioned and was not visually distinguishable $(10 \%, \mathrm{n}=110)$. Examples of

\footnotetext{
${ }^{9}$ Percentages rounded up from .5 to the nearest 1.
} 
these were posts depicting construction of exhibits where the scientific topic was unclear, ${ }^{10}$ posts representing content or activities related to STEM but lacking reference to or depiction of a particular field of science, ${ }^{11}$ and posts with ambiguous connections to science. ${ }^{12}$ Only 16 posts highlighted scientific issues of public debate or controversy; these included pollution, ocean conservation, oil spills and renewable energy.

Table 1. Representation of field of science in analyzed museum Instagram posts, in order of frequency.

\begin{tabular}{|lrr|}
\hline \multicolumn{1}{|c}{ Instagram Post Topic Area } & Frequency & Percent \% \\
\hline No science related content & 336 & 31.3 \\
Zoology (study of animals) / Wildlife Conservation & 149 & 13.9 \\
Engineering (mechanical, electrical, aviation, etc.) & 119 & 11.1 \\
Field of science not distinguishable & 110 & 10.3 \\
Paleontology / Archeology & 81 & 7.5 \\
Physics and /or Astronomy & 69 & 6.4 \\
Entomology (study of insects) & 53 & 4.9 \\
Other Life Science (biology, microbiology, & 41 & 3.8 \\
medicine, etc.) & & \\
Geology / Geoscience / Earth Science / Climate / & 39 & 3.6 \\
Hydrology / Oceanography & & \\
Plant Science & 22 & 2.1 \\
Other & 20 & 1.9 \\
Controversial Science Topic & 16 & 1.5 \\
Chemistry & 10 & .9 \\
Food Science & 5 & .5 \\
Agriculture / Land management & 2 & .2 \\
Other / Missing & 21 & 2.0 \\
Total & $\mathbf{1 0 7 3}$ & $\mathbf{1 0 0}$ \\
\hline
\end{tabular}

Types of content posted by science museums on Instagram

We addressed RQ2 by identifying and quantifying common types of content or objects depicted in science museum Instagram posts. All content types coded are listed in Table 2, in order of frequency. Of all of the posts, 30\% $(n=343)$ featured a fun, promotional or educational activity (or promotion of such an activity). ${ }^{13}$ Other common content themes included public-facing museum exhibits (a photo/video of a completed or partial exhibit within the museum; $19 \%$ of posts, $n=203)^{14}$ and specimens or natural objects (e.g. an individual animal, plant, mineral, fossil or scientific illustration of an existing or extinct animal, cells under a microscope,

\footnotetext{
${ }^{10}$ Examples: https://www.instagram.com/p/BKQ0hKKBRpC/.

${ }^{11}$ Examples: https:/ / www.instagram.com/p/BKjeerajFIA/, https://www.instagram.com/p/BK1b_KBjnlc/.

${ }^{12}$ Examples: https://www.instagram.com/p/BKTJxcNA0Zl/.

${ }^{13}$ Examples: https://www.instagram.com/p/BKGB2_ZgC3x/, https:/ /www.instagram.com/p/BKlx_m4gAEq/, https://www.instagram.com/p/BJXwJ8ag6KZ/, https://www.instagram.com/p/BKzL6sJgA3R/, https://www.instagram.com/p/BKts490jujN/.

${ }^{14}$ Examples: https://www.instagram.com/p/BKjXQGBBYic/, https:/ / www.instagram.com/p/BKbcxSegZ-h/, https://www.instagram.com/p/BKqVFq6hIRU/.
} 
planet(s), star(s), etc.) either specifically identified in the post caption (19\% of posts, $\mathrm{n}=201)^{15}$ or unidentified $(8 \%$ of posts, $\mathrm{n}=82) .{ }^{16}$ Few posts featured a science demonstration or hands-on activity $(8 \%, \mathrm{n}=82)^{17}$ or behind-the-scenes museum activity such as exhibit construction and set-up $(5 \%, \mathrm{n}=51)^{18}$ or museum research, curation or collections work $(4 \%, \mathrm{n}=48) .{ }^{19}$

Table 2. Common types of content / objects depicted in science museum Instagram posts, in order of frequency.

\begin{tabular}{|lrr|}
\hline \multicolumn{1}{|c}{ Content Type } & Frequency & Percent \% \\
\hline Other museum activity (fun, promotional, educational & 323 & 30.1 \\
activity or field, trip, etc.) & 203 & 18.9 \\
A completed museum exhibit or part of exhibit & 201 & 18.7 \\
A visual of identified* specimen(s) or natural object(s) & 135 & 12.6 \\
Technology / Scientific technology & 82 & 7.6 \\
A science demo or hands-on activity & 82 & 7.6 \\
A visual of unidentified specimen(s) or natural object(s) & & \\
Behind the scenes of museum activities NOT related to & 51 & 4.8 \\
research, curation or collections (e.g. exhibit construction, & & \\
maintenance, set-up, etc.) & & \\
Behind the scenes of museum research, curation, collections & 48 & 4.5 \\
work & $\mathbf{1 0 7 3}$ & $\mathbf{1 0 0 . 0}$ \\
Total & &
\end{tabular}

\section{Human element in science museum Instagram posts}

We addressed RQ3 by investigating how often scientists or museum researchers were visibly portrayed and identified in science museums' Instagram posts. There was a visual human element in $46 \%(n=493)$ of the Instagram posts; $8 \%(n=38)$ of these posts included humans without showing their heads or faces (e.g. hands only). When humans were present, they most often appeared to be museum audiences (adults not identified or depicted as museum staff or scientists; $28 \%, \mathrm{n}=$ $136)$, and they most often appeared in groups, with and $24 \%(n=116)$ including a single individual, $39 \%(\mathrm{n}=192)$ including multiple people ( $2-5$ people) and $29 \%(\mathrm{n}$ $=144$ ) including more than 5 people.

Only $11 \%(n=54)$ of the posts including a human element depicted identifiable science professionals (scientists, researchers, engineers, museum curators or curatorial interns, astronauts or other subject experts $\left.{ }^{20}\right)$. Of the images including a science professional, $41 \%(\mathrm{n}=22)$ included at least one female science professional, while $77 \%(n=41)$ included at least one male science professional. A majority of

\footnotetext{
${ }^{15}$ Examples: https://www.instagram.com/p/BKk2Iw7AJdk/.

${ }^{16}$ Examples: https:/ / www.instagram.com/p/BKYhEvQhJN-/.

${ }^{17}$ Examples: https://www.instagram.com/p/BKexYTCgOXo/, https:/ /www.instagram.com/p/BKexYTCgOXo/.

${ }^{18}$ Examples: https:/ /www.instagram.com/p/BKlhFP7j9Rk/.

${ }^{19}$ Examples: https:/ /www.instagram.com/p/BKiybZqAi6j/, https:/ / www.instagram.com/p/BKn3cich0jN/, https:/ / www.instagram.com/p/BKGJtZRh49I/.

${ }^{20}$ Examples: https://www.instagram.com/p/BKjjtTZhRvD/, https://www.instagram.com/p/BKGJtZRh49I/.
} 
these images, or $77 \%(\mathrm{n}=41)$, included Caucasian science professional(s), while only $6 \%(\mathrm{n}=3)$ included Black science professional $(\mathrm{s}),{ }^{21}$ a single image included an Asian / Asian American science professional and none of the images included Hispanic / Latino or Native American scientists. Science professionals were typically shown in a research context, conducting scientific research / work or museum curation work $(43 \%, \mathrm{n}=23)$ or another professional context such as giving a science talk, doing non-research museum work, demonstrating science to audiences, etc. $(50 \%, \mathrm{n}=27)$. They were never shown in a personal context such as enjoying hobbies or life outside of museum work. Several of the scientists were historical figures featured in old photographs. ${ }^{22}$ Only a handful of posts featured scientists at work "behind the scenes" on research, exhibits, collections, etc. See Table 3.

Table 3. Humans identifiable by role in museum Instagram posts, in order of frequency.

\begin{tabular}{|lrrr|}
\hline \multicolumn{1}{|c}{ Type of Human Figure } & Frequency & Percent \% & Valid Percent \% \\
\hline Children / Young adolescents & 145 & 13.5 & 29.4 \\
Museum audiences & 136 & 12.7 & 27.6 \\
Museum staff/ volunteers: museum & & & \\
communicators / Educators / Working & & & 18.7 \\
staff or volunteers not identified as & 92 & 8.6 & \\
researchers & & & \\
Science professionals (Scientists / & & & \\
Researchers / Museum curators or & & & \\
curatorial interns / Lab managers / Student & 54 & 5.0 & \\
researchers / Subject experts / Astronauts / & & & \\
Engineers) & & & \\
Celebrities / Performers / Artists & 44 & 4.1 & 2.0 \\
News media professionals & 17 & 1.6 & 2.6 \\
Technician / IT / Construction personnel & 13 & 1.2 & 2.2 \\
Public figures / politicians / policy makers & 11 & 1.0 & $\mathbf{1 0 0 . 0}$ \\
None of the above clearly distinguishable & 124 & 11.6 & \\
Total & 493 & & \\
\hline
\end{tabular}

\section{Communication approaches in science museum Instagram posts}

We addressed RQ4 by investigating the extent to which science museums' Instagram content was information-driven, promotional, entertainment-driven and/or mobilizing. These "communication approach" categories were coded independently (percentages do not add to $100 \%$ ).

A majority or $70 \%(n=752)$ of the posts were promotional in nature, being dominated by content that promoted the museum or an exhibit, event, facility, staff activity, etc. ${ }^{23}$ Roughly one-third of the posts or $35 \%(n=377)$ were mobilizing, including a call to action. Examples were calls to tag the museum in images/selfies,

\footnotetext{
${ }^{21}$ Example: https://www.instagram.com/p/BI0EpjJB0KR/.

${ }^{22}$ Example: https://www.instagram.com/p/BKqzrU5hUpo/.

${ }^{23}$ Examples: https:/ / www.instagram.com/p/BKtzNSBAlCH/, https://www.instagram.com/p/BKq_JkNDK6x/.
} 
visit a current or upcoming exhibit, visit a museum-related link/website, participate in a museum science-related activity or use a particular hashtag. Only $22 \%$ of the posts $(n=238)$ were informational in nature, being dominated by educational content, scientific information, history of science, etc. ${ }^{24}$ Promotional posts tended to also be mobilizing (Phi coefficient $=.40, \mathrm{p}<.01$ ) but not informational in terms of providing substantial educational or scientific content (Phi coefficient $=-.4, \mathrm{p}<.01)$. A little over half or $57 \%(\mathrm{n}=606)$ of the posts were entertainment-driven, dominated by content that was explicitly humorous, awe-inspiring, emotionally stimulating, story-driven, visually intriguing, fun/inspirational, etc. ${ }^{25}$ There was a weak positive association between informational and entertainment-driven $\operatorname{content}^{26}$ (Phi coefficient $=.09, \mathrm{p}<.01$ ), but a weak negative association between entertainment-driven and promotional content (Phi coefficient $=-.28, \mathrm{p}<.01$ ).

We also investigated how the communication approach reflected in individual posts impacted engagement in terms of likes and comments (RQ4a). In a linear regression model including the four different communication approach categories described above as well as other factors that may impact engagement, including number of account followers, the presence of hashtags and the presence of a human element, we found that informational $(\beta=.09, \mathrm{p}<.01)$ and entertainment-driven $(\beta$ $=.15, \mathrm{p}<.001)$ approaches significantly and positively predicted viewer likes, model summary: $R^{2}=.378 ; F(7,1059)=91.92, \mathrm{p}<.001$. A promotional approach, however, negatively predicted viewer likes $(\beta=-.1, \mathrm{p}<.01)$. See Table 4 .

In another linear regression analysis predicting post comments including the same factors as those described above, only account followers $(\beta=.49, \mathrm{p}<.001)$ and a mobilizing approach (e.g. a call to action) $(\beta=.06, \mathrm{p}<.05)$ significantly and positively predicted viewer comments, model summary: $R^{2}=.253 ; F(7,1066)=51.21$, $\mathrm{p}<.001$.

\section{Public engagement in science museum Instagram posts}

We addressed RQ5 by investigating to what extent science museums portray and encourage public engagement with science via their Instagram posts. Only 12\% (n $=125$ ) of the posts depicted meaningful public engagement or participation with science, for example museum audiences engaging with scientists, ${ }^{27}$ engaging with science or the natural world, ${ }^{28}$ speaking to a scientist ${ }^{29}$ or attending a science talk, participating in a science demonstration or doing a hands-on science activity. ${ }^{30}$ Most of these posts portrayed a hands-on science activity or demonstration, while

\footnotetext{
${ }^{24}$ Examples: https://www.instagram.com/p/BKY7ilbhd6Z/, https://www.instagram.com/p/BKnvJQKhryD/, https://www.instagram.com/p/BIaRnAChVw4/.

${ }^{25}$ Examples: https://www.instagram.com/p/BKb5b92ha14/, https://www.instagram.com/p/BKlo9ODAM0k/,

https:/ / www.instagram.com/p/BKtG5mjAGGG/, https:/ /www.instagram.com/p/BKyIXShj45B/, https:/ /www.instagram.com/p/BKxRCThD1gR/, https://www.instagram.com/p/BJ5s9vthKiV/.

${ }^{26}$ Example: https:/ / www.instagram.com/p/BKoJQKthI41/.

${ }^{27}$ Example: https://www.instagram.com/p/BKJSbZuDJEL/.

${ }^{28}$ Example: https:/ /www.instagram.com/p/BKdoyG5hP1L/.

${ }^{29}$ Example: https://www.instagram.com/p/BJ6eR2rAoA_/.

${ }^{30}$ Examples: https://www.instagram.com/p/BKdg3OMArg5/, https:/ / www.instagram.com/p/BJGahmGgYKC/, https:/ /www.instagram.com/p/BJf0agAAYlN/.
} 
Table 4. Results of Linear Regression Analysis Predicting Instagram Post Likes.

\begin{tabular}{|lcr|}
\hline \multicolumn{1}{|c}{ Model } & Standardized Regression Coefficient $(\beta)$ & \multicolumn{1}{c|}{$\mathrm{t}$} \\
\hline IG account followers & $.52^{* * *}$ & 21.08 \\
Hashtags & $.06^{*}$ & 2.28 \\
Human element & .02 & .89 \\
Informational & $.09^{* *}$ & 3.46 \\
Entertainment-driven & $.15^{* * *}$ & 5.66 \\
Mobilizing & .002 & .61 \\
Promotional & $-.10^{* *}$ & -3.44 \\
F total & $91.92^{* * *}$ & \\
$R^{2}$ & .378 & \\
\hline$* * *{ }^{*}<001^{* *}<01^{*}{ }^{*}<05$ & & \\
\hline
\end{tabular}

posts showing or telling stories of non-scientists or museum visitors interacting with scientists/researchers were less common. Very few of the Instagram posts encouraged public participation in science or highlighted citizen science activities.

\section{Science as a process in science museum Instagram posts}

To address RQ6, we investigated the extent to which science museums are communicating their research activities on Instagram as well as the extent to which they are portraying science as a process as opposed to a series of products (e.g. artifacts, specimens). Less than $1 \%$ or only 8 posts total discussed or provided information about or related to a recent scientific discovery or finding. Most of these were published by accounts belonging to research institutions such as Woods Hole, ${ }^{31}$ although some museum posts highlighted recent findings or newly discovered species. ${ }^{32}$ For example, Columbus' Dynamic Hands-On Science Center regularly publishes clips of "Science Now" videos featuring a scientist talking about recent research findings.

Most of the posts containing any science-related content presented science as a product as opposed to a process. Only $10 \%$ of the posts $(n=70)$ depicted science as a process, by for example educating viewers about the scientific method or process of discovery, showing research in progress, ${ }^{33}$ discussing the creation of scientific knowledge, ${ }^{34}$ telling the story of a discovery or specimen collection, ${ }^{35}$ etc. See Table 5.

\section{Scientific information in science museum Instagram post captions}

We investigated the captions of museum Instagram posts for substantive scientific information. In doing so, we also looked at the types of hashtags museums used to

\footnotetext{
${ }^{31}$ Example: https://www.instagram.com/p/BKIVY9qAl8K/.

${ }^{32}$ Examples: https:/ /www.instagram.com/p/BKoeMTXhiGF/, https:/ / www.instagram.com/p/BKWAdzvDfkv/.

${ }^{33}$ Example: https:/ / www.instagram.com/p/BKtbq9lhVDt/.

${ }^{34}$ Example: https:/ / www.instagram.com/p/BKjJW5lhnVp/.

${ }^{35}$ Examples: https://www.instagram.com/p/BKa7uZwAFEg/, https://www.instagram.com/p/BKds-0LhL9O/.
} 
Table 5. Extent to which museum Instagram posts portray science as a process, public engagement and news of scientific discoveries. Valid percent based only on posts including any science-related content. The categories/codes included in the table are not mutually exclusive.

\begin{tabular}{|lrrr|}
\hline Characteristic of Instagram Post & Frequency & Percent \% & Valid Percent \% \\
\hline Science as a process & 70 & 6.5 & 9.5 \\
Scientific discovery & 8 & .7 & 1.1 \\
Public Engagement & 125 & 11.6 & 11.7 \\
\hline
\end{tabular}

tag their posts. Only 10\% $(n=105)$ of the Instagram posts provided captions with substantive scientific information, or more than a superficial one-liner describing the technical content of a visual. We also found that while a majority of the posts or $81 \%$ $(n=865)$ included hashtag(s) in their captions, only $48 \%$ of these $(n=410)$ included science-related hashtags (\#biology, \#python, etc.) A majority of the posts containing hashtags or $77 \%(n=658)$ has hashtags that were museum branded or campaignrelated (e.g. \#FranklinInstitute). Only 21\% $(\mathrm{n}=184)$ included hashtags that were inspirational or comical (\#museumsarecool, \#ilovemyjob, \#weirdanimals, etc.)

The modern museum struggles to be more than just a physical place, to become a collaborative, digitally-enhanced, virtually-accessible information and learning space. Social networks can help museums meet their missions among new audiences and in new ways. Instagram, in particular, is an exciting platform for museums, as a network that caters to young internet users with the power of visuals and personal storytelling. Museums can use Instagram to transform specimens and behind-the-scenes collections into interactive digital "artifacts," and to mediate online interaction between scientists and museum visitors.

Despite Instagram's potential applications for online learning, public engagement and public visibility of scientists, we discovered in our analysis of over a thousand Instagram posts that most science and natural history museums are using Instagram to promote their public-facing exhibits and activities, missing opportunities to raise awareness of the inner workings of the museum. This extends previous conclusions [Fletcher and Lee, 2012; Lazzeretti, Sartori and Innocenti, 2015] that museums are primarily using social media tools for traditional, one-way, promotional messaging. If the museums we included in our analysis are indeed focused on public engagement, this is certainly not reflected in their Instagram posts.

This study addresses a dearth of professional and academic understanding of how science museums are using visually-centered social media networks. In a content analysis 1,073 science museum Instagram, we found a consistent lack of robust scientific material, science-related hashtags and scientists' faces, among other elements that might help communicate science or encourage public participation with it. Nearly a third of the posts contained no obviously science-related content at all. The museum Instagram accounts we looked at are using the platform primarily to promote events and/or to share their activities from a 30,000 foot view, often with lifeless images of exhibits or photos of museum visitors engaging in nondescript activities, without meaningful captioning. 
Based on our analysis of science museums' Instagram posts, most of these organizations are not tapping into the platform's potential as a window into the scientific life of the museum, for example through features of researchers, glimpses of behind-the-scenes activities or highlights of citizen science inside and outside the museum. Posts featuring such content have the potential to inspire museum audiences to engage in scientific activities in their daily lives and to see themselves as citizen curators for a living museum. As a rare example of this, see the Burke Museum's popular post ${ }^{36}$ about a father and daughter who found a fossilized tooth on the beach and brought it into the museum to be identified by Burke's vertebrate paleontology curator. Only $11 \%$ of the posts we analyzed visually depicted science professionals, and less than $10 \%$ depicted science as a process. Depictions of public engagement with science or interactions with scientists were equally rare, as were visuals from behind the scenes of museum research, curation or collections. The later activities are all incredibly important components of the work of modern natural history museums, especially those affiliated with universities and other research institutions, yet are underrepresented activities in museums' Instagram accounts.

We also found that surprisingly few museum Instagram posts feature human faces, especially the faces of science and museum professionals. Previous research has established a higher level of viewer engagement with visuals that include a human element, particularly faces [Bakhshi, Shamma and Gilbert, 2014]. Yet less than half of visuals we analyzed included a human element. Science museums have an opportunity to fill a gaping hole in terms of showcasing scientists and museum researchers as relatable, warm human beings [Fiske and Dupree, 2014]. Instagram is the perfect platform to initiate visual campaigns to humanize scientists, such as the \#scientistswhoselfie movement, if only more museums would seize the opportunity.

\section{Limitations and future research}

Science museums' promotional approaches to Instagram may reflect a broader lack of public engagement activities inside and outside museum walls. It's possible and very likely that most museums still have a long way to go to establish public engagement as a primary component of their offerings, and that our findings reflect this fact. For example, if few science museums today employ active researchers or if they only infrequently create opportunities for public engagement or citizen science, their Instagram posts may simply reflect their day-to-day operations and offerings. However, we don't think this fully explains the stark lack of educational, mobilizing and scientist-humanizing content within most science museum's Instagram feeds. Even if most science museums today operate on the deficit model and offer primarily exhibits and activities focused on science end products, they could still be highlighting their staff members, offering insights into their exhibit creation, providing basic science explainers, etc. Also, even university-affiliated science museums with a heavy focus on research and public engagement are falling into trap of using Instagram as a promotional tool instead of a means for audiences to engage with museum researchers and their work.

Our findings don't consider the point of view of the employees and communication staff of the museums that we included in our analyses. Future studies based

\footnotetext{
36https: / / www.instagram.com/p/BKJSbZuDJEL/?taken-by=burkemuseum.
} 
on qualitative approaches, for example expert interviews or surveys of museum communication staff, might explore the motivations behind their approaches to museum Instagram posting, potential barriers to highlighting museum researchers or promoting education and public engagement through museum Instagram posts, etc.

\section{Summary}

We have identified a gap in museum Instagram content that promotes scientific literacy, showcases scientists' and citizen scientists' work, communicates science to an active audience of current and prospective museum visitors, and invites users to join museums on adventures of scientific collection and knowledge creation. Visuals of science in progress and educational captions are underrepresented within U.S. science museums' Instagram posts. We invite more science museums to add value to the science communication landscape on Instagram by creating educational visuals and captions and by encouraging public engagement in science, for example through featuring museum researchers and their work behind-the-scenes, inviting viewer questions and participation, highlighting participatory museum work and activities, etc. Science museums could also be leveraging Instagram "stories", IGTV and live videos [Stucchi, 2017] to highlight museum researchers and tell more stories of scientific discovery in action, with public input. By approaching Instagram less as a one-way promotional tool and more as a conversation-starting, inspirational visual space to bring museum researchers and the public together, museums might address their public engagement goals in new ways.

\section{References}

Arnold, K. (1996). 'Presenting science as product or as process: museums and the making of science'. New Research in Museum Studies 6, pp. 57-78.

Badell, J.-I. (2015). 'Museums and social media: Catalonia as a case study'. Museum Management and Curatorship 30 (3), pp. 244-263. https://doi.org/10.1080/09647775.2015.1042512.

Bakhshi, S., Shamma, D. A. and Gilbert, E. (April 2014). 'Faces engage us: photos with faces attract more likes and comments on Instagram'. In: Proceedings of the 32nd annual ACM conference on Human factors in computing systems - CHI '14. ACM Press, pp. 965-974. https://doi .org/10.1145/2556288.2557403.

Ballard, H. L., Robinson, L. D., Young, A. N., Pauly, G. B., Higgins, L. M., Johnson, R. F. and Tweddle, J. C. (2017). 'Contributions to conservation outcomes by natural history museum-led citizen science: examining evidence and next steps'. Biological Conservation 208, pp. 87-97. https://doi.org/10.1016/j.biocon.2016.08.040.

Bandelli, A. and Konijn, E. A. (2013). 'Science centers and public participation: methods, strategies and barriers'. Science Communication 35 (4), pp. 419-448. https://doi.org/10.1177/1075547012458910.

Bik, H. M. and Goldstein, M. C. (2013). 'An Introduction to Social Media for Scientists'. PLoS Biol. 11 (4), e1001535. https://doi.org/10.1371/journal.pbio.1001535.

Bombaci, S. P., Farr, C. M., Gallo, H. T., Mangan, A. M., Stinson, L. T., Kaushik, M. and Pejchar, L. (2016). 'Using Twitter to communicate conservation science from a professional conference'. Conservation Biology 30 (1), pp. 216-225. https://doi.org/10.1111/cobi.12570. 
Bonetta, L. (2007). 'Scientists Enter the Blogosphere'. Cell 129 (3), pp. 443-445. https://doi.org/10.1016/j.cell.2007.04.032.

Bonney, R., Phillips, T. B., Ballard, H. L. and Enck, J. W. (2015). 'Can citizen science enhance public understanding of science?' Public Understanding of Science 25 (1), pp. 2-16. https://doi.org/10.1177/0963662515607406.

Bowler, M. T., Buchanan-Smith, H. M. and Whiten, A. (2012). 'Assessing Public Engagement with Science in a University Primate Research Centre in a National Zoo'. PLoS ONE 7 (4), e34505.

https://doi.org/10.1371/journal.pone.0034505.

Brossard, D. (2013). 'New media landscapes and the science information consumer'. Proceedings of the National Academy of Sciences 110 (Supplement 3), pp. 14096-14101. https://doi .org/10.1073/pnas.1212744110. PMID: 23940316.

Budge, K. (2017). 'Objects in focus: museum visitors and Instagram'. Curator: The Museum Journal 60 (1), pp. 67-85. https://doi.org/10.1111/cura.12183.

Collins, K., Shiffman, D. and Rock, J. (2016). 'How are scientists using social media in the workplace?' PLOS ONE 11 (10), e0162680. https://doi.org/10.1371/journal. pone.0162680.

Cornu, B. (2004). 'Networking and collective intelligence for teachers and learners'. In: World Yearbook of Education 2004. Digital technologies, communities and education. Ed. by A. Brown and N. Davis. London, U.K.: Routledge.

Druckman, J. N. and Bolsen, T. (2011). 'Framing, motivated reasoning, and opinions about emergent technologies'. Journal of Communication 61 (4), pp. 659-688. https://doi.org/10.1111/j.1460-2466.2011.01562.x.

Duggan, M. (2015). Mobile messaging and social media 2015. URL: http://www . pewinternet.org/2015/01/09/social-media-update-2014/.

Fink, K. and Schudson, M. (2014). 'The rise of contextual journalism, 1950s-2000s'. Journalism: Theory, Practice \& Criticism 15 (1), pp. 3-20. https://doi.org/10.1177/1464884913479015.

Fisher, J. (2016). 'Curators and Instagram: affect, relationality and keeping in touch'. Journal of Curatorial Studies 5 (1), pp. 100-123. https://doi.org/10.1386/jcs.5.1.100_1.

Fiske, S. T. and Dupree, C. (2014). 'Gaining trust as well as respect in communicating to motivated audiences about science topics'. Proceedings of the National Academy of Sciences 111 (Supplement 4), pp. 13593-13597. https://doi.org/10.1073/pnas.1317505111.

Fletcher, A. and Lee, M. J. (2012). 'Current social media uses and evaluations in American museums'. Museum Management and Curatorship 27 (5), pp. 505-521. https://doi.org/10.1080/09647775.2012.738136.

Green, H. and Hannon, C. (2006). Their space. Education for a digital foundation. London, U.K.

URL: https: //www.demos.co.uk/files/Their $\% 20$ space $\% 20-\% 20$ web.pdf (visited on October 2016).

Hill, A., Guralnick, R., Smith, A., Sallans, A., Gillespie, R., Denslow, M., Gross, J., Murrell, Z., Conyers, T., Oboyski, P., Ball, J., Thomer, A., Prys-Jones, R., Torre, J. de la, Kociolek, P. and Fortson, L. (2012). 'The notes from nature tool for unlocking biodiversity records from museum records through citizen science'. ZooKeys 209, pp. 219-233. https://doi .org/10.3897/zookeys. 209.3472. 
Hine, A. and Medvecky, F. (2015). 'Unfinished Science in Museums: a push for critical science literacy'. JCOM 14 (02), A04. URL: https://jcom.sissa.it/archive/14/02/JCOM_1402_2015_A04.

Illingworth, S., Redfern, J., Millington, S. and Gray, S. (2015). 'What's in a Name? Exploring the Nomenclature of Science Communication in the U.K.' F1000Research 4 (409). v1; ref status: awaiting peer review. https://doi.org/10.12688/f1000research.6858.1.

Instagram (2016). Number of monthly active Instagram users from January 2013 to June 2016 (in millions). URL: https://www. statista.com/statistics/253577/numbe r-of-monthly-active-instagram-users/ (visited on 1st November 2016).

Jarreau, P. B. and Porter, L. (2016). 'Science in the social media age: profiles of science blog readers'. In: Annual meeting of the AEJMC (Hilton Minneapolis, Minneapolis, MN, U.S.A. 4th August 2016).

Jensen, B. (October 2013). 'Instagram as cultural heritage: user participation, historical documentation and curating in museums and archives through social media'. In: 2013 Digital Heritage International Congress (DigitalHeritage). Vol. 2. IEEE, pp. 311-314. https://doi.org/10.1109/digitalheritage.2013.6744769.

Jensen, E. and Buckley, N. (2014). 'Why people attend science festivals: interests, motivations and self-reported benefits of public engagement with research'. Public Understanding of Science 23 (5), pp. 557-573.

Ke, Q., Ahn, Y.-Y. and Sugimoto, C. R. (2017). 'A systematic identification and analysis of scientists on Twitter'. PLOS ONE 12 (4), e0175368. https://doi.org/10.1371/journal.pone.0175368.

Kelly, L. (2010). 'How Web 2.0 is changing the nature of museum work'. Curator: The Museum Journal 53 (4), pp. 405-410. https://doi.org/10.1111/j.2151-6952.2010.00042.x.

Lapointe, P. and Drouin, J. N. (2007). Science, on blogue!: le nouveau monde d'Internet. Canada: Multimondes.

Lazzeretti, L., Sartori, A. and Innocenti, N. (2015). 'Museums and social media: the case of the museum of natural history of Florence'. International Review on Public and Nonprofit Marketing 12 (3), pp. 267-283. https://doi.org/10.1007/s12208-015-0136-5.

Lee, A. M. and Chyi, H. I. (2014). 'Motivational consumption model: exploring the psychological structure of news use'. Journalism $\mathcal{E}$ Mass Communication Quarterly 91 (4), pp. 706-724. https://doi.org/10.1177/1077699014550088.

Long, M. and Steinke, J. (1996). 'The thrill of everyday science: images of science and scientists on children's educational science programmes in the United States'. Public Understanding of Science 5 (2), pp. 101-119. https://doi.org/10.1088/0963-6625/5/2/002.

Losh, S. C. (2010). 'Stereotypes about scientists over time among U.S. adults: 1983 and 2001'. Public Understanding of Science 19 (3), pp. 372-382. https://doi.org/10.1177/0963662508098576.

Lovejoy, K. and Saxton, G. D. (2012). 'Information, community and action: how nonprofit organizations use social media'. Journal of Computer-Mediated Communication 17 (3), pp. 337-353. https://doi.org/10.1111/j.1083-6101.2012.01576.x. 
Luzón, M. J. (2013). 'Public Communication of Science in Blogs: Recontextualizing Scientific Discourse for a Diversified Audience'. Written Communication 30 (4), pp. 428-457. https://doi.org/10.1177/0741088313493610.

Mangold, W. G. and Faulds, D. J. (2009). 'Social media: the new hybrid element of the promotion mix'. Business Horizons 52 (4), pp. 357-365. https://doi.org/10.1016/j.bushor.2009.03.002.

Marty, P. F. (2016). 'The cobbler's children'. In: Annual Review of Cultural Heritage Informatics. Ed. by J. W. Arns. Lanham, MD, U.S.A.: Rowman \& Littlefield Publishers, pp. 19-22.

Mollett, A., Brumley, C., Gilson, C. and Williams, S. (3rd May 2017). [Blog post]. Impact of Social Sciences Blog. URL: http://blogs. lse.ac.uk/impactof socialsc iences/2017/05/03/science-communication-and-social-media-from-iconi c-nasa-moon-landings-to-instagramming-astronauts/.

Nisbet, M. C., Scheufele, D. A., Shanahan, J., Moy, P., Brossard, D. and Lewenstein, B. V. (2002). 'Knowledge, Reservations, or Promise? A Media Effect Model for Public Perceptions of Science and Technology'. Communication Research 29, pp. 584-608. https://doi .org/10.1177/009365002236196.

Puschmann, C. (2014). '(Micro)Blogging Science? Notes on Potentials and Constraints of New Forms of Scholarly Communication'. In: Opening Science. Springer International Publishing, pp. 89-106. https://doi.org/10.1007/978-3-319-00026-8_6.

Riffe, D., Lacy, S. and Fico, F. G. (2005). Analyzing media messages: using quantitative content analysis in research. Mahwah, NJ, U.S.A.: Lawrence Erlbaum Associates.

Roger, E. and Klistorner, S. (2016). 'BioBlitzes help science communicators engage local communities in environmental research'. JCOM 15 (03), A06. https://doi.org/10.22323/2.15030206.

Rudloff, M. (2013). 'Scaffolding the next wave of digital visitor interaction in museums'. The International Journal of the Inclusive Museum 5 (4), pp. 9-24. https://doi.org/10.18848/1835-2014/cgp/v05i04/44411.

Russo, A., Watkins, J. and Groundwater-Smith, S. (2009). 'The impact of social media on informal learning in museums'. Educational Media International 46 (2), pp. 153-166. https://doi.org/10.1080/09523980902933532.

Salomon, D. (2013). 'Moving on from Facebook: using Instagram to connect with undergraduates and engage in teaching and learning'. College $\mathcal{E}$ Research Libraries News 74 (8), pp. 408-412. https://doi .org/10.5860/crln.74.8.8991.

Schäfer, M. S. (2009). ‘From Public Understanding to Public Engagement: An Empirical Assessment of Changes in Science Coverage'. Science Communication 30 (4), pp. 475-505. https : //doi .org/10.1177/1075547008326943.

Sefton-Green, J. (2004). Literature review in informal learning with technology outside school. Bristol, U.K.: Futurelab.

Selin, C., Rawlings, K. C., de Ridder-Vignone, K., Sadowski, J., Allende, C. A., Gano, G., Davies, S. R. and Guston, D. H. (2016). 'Experiments in engagement: designing public engagement with science and technology for capacity building'. Public Understanding of Science 26 (6), pp. 634-649. https://doi.org/10.1177/0963662515620970. 
Shanahan, M.-C. (2011). 'Science blogs as boundary layers: Creating and understanding new writer and reader interactions through science blogging'. Journalism 12 (7), pp. 903-919. https://doi .org/10.1177/1464884911412844.

Spear, D. M., Pauly, G. B. and Kaiser, K. (2017). 'Citizen science as a tool for augmenting museum collection data from urban areas'. Frontiers in Ecology and Evolution 5, 86. https://doi.org/10.3389/fevo.2017.00086.

Stilgoe, J., Lock, S. J. and Wilsdon, J. (2014). 'Why should we promote public engagement with science?' Public Understanding of Science 23 (1), pp. 4-15. https://doi.org/10.1177/0963662513518154.

Stucchi, S. (2017). How museums can leverage live streaming technology. [White paper]. URL: http://amt-lab.org/blog/2017/4/how-museums-can-leverage-live-st reaming-technology (visited on 31st January 2018).

Sturgis, P. and Allum, N. (2004). 'Science in Society: Re-Evaluating the Deficit Model of Public Attitudes'. Public Understanding of Science 13 (1), pp. 55-74. https://doi.org/10.1177/0963662504042690.

Su, L. Y.-F., Akin, H., Brossard, D., Scheufele, D. A. and Xenos, M. A. (2015). 'Science news consumption patterns and their implications for public understanding of science'. Journalism \& Mass Communication Quarterly 92 (3), pp. 597-616. https://doi.org/10.1177/1077699015586415.

Sugimoto, C. R., Work, S., Larivière, V. and Haustein, S. (2017). 'Scholarly use of social media and altmetrics: a review of the literature'. Journal of the Association for Information Science and Technology 68 (9), pp. 2037-2062. https://doi.org/10.1002/asi.23833.

Van Noorden, R. (2014). 'Online collaboration: Scientists and the social network'. Nature 512 (7513), pp. 126-129. https://doi .org/10.1038/512126a.

Weilenmann, A., Hillman, T. and Jungselius, B. (April 2013). 'Instagram at the museum: communicating the museum experience through social photo sharing'. In: Proceedings of the SIGCHI Conference on Human Factors in Computing Systems - CHI '13. ACM Press, pp. 1843-1852. https://doi.org/10.1145/2470654.2466243.

Welbourne, D. J. and Grant, W. J. (2016). 'Science communication on YouTube: factors that affect channel and video popularity'. Public Understanding of Science 25 (6), pp. 706-718. https://doi .org/10.1177/0963662515572068.

Wooden, R. (2006). 'The principles of public engagement: at the nexus of science, public policy influence and citizen education'. Social Research 73 (3), pp. 1057-1063. URL: https://www. jstor.org/stable/40971872.

Wright, D. K. and Hinson, M. D. (2008). 'How blogs and social media are changing public relations and the way it is practiced'. Public relations journal 2 (2), pp. 1-21.

Authors

Paige Brown Jarreau is Director of Social Media and Science Communication at LifeOmic, a science communication specialist at LSU, and a longtime science blogger on her blog From The Lab Bench. Her professional and research activities focus on how scientists use social media and impacts on public engagement and trust in science. E-mail: Pbrow11@lsu.edu. 
Nicole Smith Dahmen is an Associate Professor at the School of Journalism and Communication at the University of Oregon. Her research focuses on ethical and technological issues in visual communication, with an emphasis on photojournalism in the Digital Age. E-mail: ndahmen@uoregon.edu.

Ember Jones is a public relations and communications professional. She received her Master's degree in Mass Communication in 2017 from the LSU Manship School, where she worked as a research assistant. E-mail: emberdjones@gmail.com.

How to cite

Jarreau, P. B., Dahmen, N. S. and Jones, E. (2019). 'Instagram and the science museum: a missed opportunity for public engagement'. JCOM 18 (02), A06. https://doi.org/10.22323/2.18020206. 